\title{
Trying To Speak: Between Politics and Aesthetics, Darmstadt 1970-1972
}

\author{
MARTIN IDDON
}

\begin{abstract}
In the historiography of the Darmstadt Ferienkurse, the 1970s, when they are examined at all, are generally regarded as a period of stagnation, between the fervour of serial activity in the 1950s and the resurgence of the courses in the 1980s under the banner of various inflections of New Complexity. Yet, in a period of political upheaval after 1968, dissent was felt at Darmstadt too, and protests in 1970 and 1972 saw the institution at its most politically volatile. These protest movements caused the courses' director, Ernst Thomas, to institute wide-scale changes in their structure and content. Key roles in these protests were taken by journalists: indeed, clear parallels can be drawn between the seemingly egalitarian calls from journalists for Mitbestimmung (co-determination) at Darmstadt and the similar demands being made by their trade unions in the West German federation. Thomas's failure to deal with journalistic pressure and his heavy-handed treatment of individual protesters (notably Reinhard Oehlschlägel) meant that, shrewd and durable though his reinvention of the courses was, it would be only in 1982, with the accession of a new director, that the press would begin to speak positively about the Darmstadt courses once more. A close reading of these two protests shows the sometime 'citadel of the avant-garde' at a distinctly precarious moment in its history. At the time, some felt that such protests could lead to the demise of the courses, and it was far from clear whether Thomas's reforms would be successful. But, even within this period of uncertainty, the Darmstadt Ferienkurse were anything but stagnant.
\end{abstract}

\section{Introduction}

In 1970 the Darmstädter Internationale Ferienkurse für neue Musik took place for the twenty-fifth time. The cultural and institutional landscape of the 1950s, which had led to the development of the misleading notion of the Darmstadt School, was long gone. ${ }^{1}$ Along with it had departed almost every figure associated with that notion, including Pierre Boulez, Karel Goeyvaerts, Bruno Maderna, Luigi Nono, and Henri Pousseur. Of the composers for whom Darmstadt had been key in their rise to prominence, only Karlheinz Stockhausen remained as a regular lecturer. ${ }^{2}$ Since the early 1960s there had been regular criticism of the courses' content. In 1964 Cornelius Cardew suggested that Darmstadt had 'become an excellent Academy, and problems like Notation and Electronic Sound are competently handled in a rather academic way. What has got lost is the vital interest in new and serious

1 Several Darmstadt-related texts have done much to demonstrate that the idea of the Darmstadt School, especially as promulgated in Anglo-American scholarship, is a fundamentally misleading one. Chief among these are Trudu's $L a$ 'Scuola' di Darmstadt, Borio's Musikalische Avantgarde um 1960, and Attinello's 'The Interpretation of Chaos'.

2 Significantly, Stockhausen only returned to Darmstadt as a regular faculty member in 1966, after Boulez had departed for Bayreuth in 1965. 
experimental music'. ${ }^{3}$ By 1966 Wolf-Eberhard von Lewinski was moved to characterize the courses as 'a prosaic works convention' ${ }^{4}$ Much of this criticism betrayed underlying dissatisfaction with the direction the Ferienkurse had taken after the death of their founder, Wolfgang Steinecke, in $1961 . .^{5}$ Ernst Thomas, the former music editor of the Frankfurter Allgemeine Zeitung, had been officially appointed director of the Internationales Musikinstitut Darmstadt (IMD), and hence also of the Darmstadt Ferienkurse, on 1 October $1962{ }^{6}$ and it was inevitable that comparisons would be drawn between the two directors. Where Steinecke was already lionized as the visionary founder of Darmstadt, Thomas's quieter, more diffident style quickly led to perceptions of his tenure as that of a caretaker, preserving rather than advancing the events of the 1950s.

It is in this context that I shall examine some of the institutional problems and personality issues that were rife at the Darmstadt Ferienkurse in the early 1970s, and specifically two protests, in 1970 and 1972 respectively, which in their different ways set the future of Darmstadt into doubt. What Paul Griffiths calls the previous decade's 'failure of faith', attributing it somewhat narrowly to an abortive search for a common serial language, ${ }^{8}$ was by now turning into a wider crisis of belief, which questioned whether the courses could have any real validity. I shall show, however, that a great deal of this 'failure of faith' had its origins in the internal political wranglings of individuals active in the institutions of New Music in West Germany, with much of the discontent emanating from one source in particular, namely the journalist and music editor Reinhard Oehlschlägel.

Alongside this runs a second strand of inquiry, which reveals that many of the reforms normally associated with the revival of the Ferienkurse under the more colourful Friedrich Hommel, who succeeded Thomas in 1982, had earlier beginnings under Thomas's directorship. Moreover, many of these reforms were initiated not by Thomas himself, but by his newly created Programmbeirat, or advisory panel. The progressive devolution of power from what began as Thomas's 'one-man-show' was the real sign that Darmstadt could start to recover on an institutional level. ${ }^{9}$ However, by then the general perception of the Ferienkurse, so heavily damaged by the infighting I shall outline, made it impossible for this major institutional reform to become apparent until Hommel's accession. Like Steinecke, Hommel had a media-friendly image that was in sharp contrast to the widespread perception

3 Cardew, 'New Music Has Found its Feet'.

4 Lewinski, 'Alte und neue Experimente bei Kranichsteinern'; quoted in Kurtz, Stockhausen, 147. Lewinski, it should be noted, is one of the most critical of commentators on Ernst Thomas's Darmstadt. From 1951 he was active as a journalist in Darmstadt, and many had anticipated that it would be he, rather than Thomas, who would take over Darmstadt as its second director.

5 Steinecke was killed in a hit-and-run incident on 23 December 1961.

6 He had already acted as curator for the 1962 courses, the bulk of which Steinecke had planned before his death.

7 Griffiths, Thames and Hudson Encyclopaedia of 20th-Century Music, 58.

8 Whether any such search for a common language ever occurred, except in the most primitive of terms, is itself highly questionable. The rapidity with which many composers abandoned any sort of 'strict' approach to multiple serialism, and the degree to which personal variations were integrated into individual serial techniques, largely developing into entirely personalized systems with only the most tenuous links to models such as Boulez's Structure Ia, suggest that, if a common language had been a goal for some, most had abandoned this goal well before Nono's formulation of the 'Darmstadt School' in 1957 or Cage's arrival at Darmstadt in 1958, probably between 1954 and 1955.

9 Klaus Trapp refers to Thomas's direction as an 'Ein-Mann-Betrieb' ('Darmstadt und die 68-er Bewegung', 370). 
of Thomas as 'an administrator rather than a musician who simply wanted everything to run smoothly'. ${ }^{10}$ While there is certainly truth in such estimations of Thomas, a simplistic characterization of this kind tends to negate the positive aspects of his reign. Even though Thomas almost invariably had to be pressurized into making changes, the restructuring of Darmstadt that he undertook was an extremely astute one. Moreover, it was precisely these institutional changes upon which Hommel was later to capitalize. ${ }^{11}$ In short, if Thomas was an administrator rather than a musician, he was a fine administrator, who responded to problems on both institutional and structural levels with imagination and resolve. He was, as Sellar and Yeatman might have put it, ${ }^{12}$ a good man but a bad king.

\section{Student Protest. The Darmstadt Delegation}

The year 1970 was the twenty-fifth occasion of the Darmstadt Ferienkurse. ${ }^{13}$ Although Ernst Thomas had not planned any particular celebratory events, the town of Darmstadt itself, still the courses' principal benefactor, provided the money for a composition competition. Since 1952 there had been a performers' prize, the Kranichsteiner Musikpreis, which had been awarded (normally to several recipients) every year until 1962, and since then only in 1967 and 1969. This, however, was the first time in the courses' history that a prize for composition was to be awarded. The competition was divided into two sections, each with a first and a second prize. The first section, with awards of 8000 and 4000 marks, was for an orchestral piece, with the optional inclusion of soloists, choir, or tape. The second was for a chamber work (scored for up to six players), a work for unaccompanied choir (up to sixteen voices), or an electronic work. The awards for this section were of 6000 and 3000 marks, raising the total available prize money to the substantial sum of 20,000 marks. The jury had five members, each of them established regulars at Darmstadt: Günther Becker, Heinz Enke, Aloys Kontarsky, Bruno Maderna, and Otto Tomek. Only Maderna and Becker were recognized composers; Enke and Tomek were both primarily broadcast journalists. ${ }^{14}$ Kontarsky, of course, was a well-known Darmstadt figure, both as a member of the teaching faculty and as the pianist in the Stockhausen Ensemble.

In the event, the competition attracted 102 scores from seventy-six composers hailing from twenty-five different countries. Despite this exceptionally high level of interest, after fourteen days of 'vague rumours about the awarding or non-awarding' of the prizes during the Ferienkurse, only one score was selected to receive a prize, and even then only a second

10 Attinello, 'The Interpretation of Chaos', 6.

11 Although I do not dwell on this point here, it is worth adding that Thomas's reorganization of the composition faculty after Stockhausen's departure following the 1974 courses was also an important factor in Hommel's success. Most of the composers who came to be regarded as leaders in the European New Music scene in the 1980s, and were later intimately linked to Hommel's Darmstadt, were first invited to the Ferienkurse by Thomas. Foremost among these were Brian Ferneyhough, Gérard Grisey, Helmut Lachenmann, and Wolfgang Rihm.

12 Authors of 1066 and All That (1930).

13 The actual twenty-fifth anniversary of the Ferienkurse, founded in 1946, fell a year later in 1971. Ironically, that year would be the first since Darmstadt's foundation in which no courses took place.

14 Enke and Tomek represented the Hessischer Rundfunk (HR) and the Südwestfunk (SWF) respectively. Thomas was later criticized for the level of influence he had allowed Tomek to have on his thinking. 
prize. ${ }^{15}$ The piece in question was Nicolaus A. Huber's Versuch über Sprache for sixteen solo voices, hammond organ, double bass, and two 'obbligato' loudspeaker channels. ${ }^{16}$ Wolfgang Becker reported the reasons behind the jury's selection:

The extent of the non-musically predetermined interpolations was so considerable that it was impossible to gain a precise idea of the sonic form of the works. As a consequence, only two scores were admitted to the final judging, and it was decided only after the performance to confer a second prize, as it was impossible to award the first prize. ${ }^{17}$

Despite this explanation, the implicit message from the jury was that the standard of submissions was insufficiently high. Indeed, Stockhausen was quoted as stating categorically: 'There is nobody talented any more.' ${ }^{18}$ Lewinski strengthened this view by defending the courage of the jury's decision. In his opinion, to have awarded all four available prizes would have meant an unacceptable lowering of standards. ${ }^{19}$ Worse still for the competition organizers, Huber's piece was itself heavily booed at its first performance. ${ }^{20}$ It is worth wondering whether this display of dissatisfaction represented a reaction to the piece itself, or a protest by the many refused composers represented in the audience. Such disquiet cannot have been helped by Reinhard Oehlschlägel's report, which suggested that Huber would have been awarded the first prize had he not used a text from Karl Marx among the various fragments in Versuch über Sprache. ${ }^{21}$ Ernst Thomas refuted this claim, observing that the score did not provide the sources of the material, and that the jury could therefore not have known the provenance of the text. ${ }^{22}$

The problems over the 1970 composition competition came after many years of underlying discontent among the participants. It is perhaps worth mentioning three of the most

15 'Nach den 14 Tagen mag es der Darmstädter Jury leichterfallen, nach dem dunklen Gemunkel über die Verleihung beziehungsweise Nichtverleihung der ausgeschriebenen Kompositionspreise zu beteuern, es sei wirklich nicht mehr Preiswürdiges eingesandt worden' (Bach, 'Laute Mißtöne bei den Darmstädter Kursen’).

16 'In Darmstadt blast ein frischer Wind', Basler Nachrichten, 16 September 1970.

17 'La parte degli interventi non musicalmente prestabiliti era così grande che era impossibile farsi un'idea precisa della forma sonora delle opere. Di conseguenza soltanto due partiture [. . . furono ammesse alla prova finale e soltanto dopo l'esecuzione fu deciso di attribuire un secondo premio, nell'impossibilità di conferire il primo premio' (Becker, 'Da Darmstadt: i corsi estivi della nuova musica', 1163). The other score admitted to the final judging was by Hans Darmstadt. As Darmstadt was a pupil of one of the judges, Günther Becker, it may have been deemed inappropriate to award a prize to him.

18 'Keine Talente mehr' ('Kritik an den Etablierten', Hessische Allgemeine, 10 September 1970).

19 Lewinski, 'Auch ein nacktes Mädchen kann die Moderne nicht retten'.

20 'Gefährdetes Forum der Avantgarde', Weser-Kurier, 8 September 1970. During the IMD's archive recording of this performance there is sustained booing throughout the last two minutes of the fifteen-minute piece, and occasional booing throughout.

21 Oehlschlägel, 'Dokumentation und Preis'. This suggestion was strongly denied by Ernst Thomas, who stated that Oehlschlägel had misunderstood a comment made by the mayor, Ludwig Engel, at the official ceremony of the 1970 course. Thomas would find cause to use these words against Oehlschlägel only two years later, during the controversy of 1972.

22 'Sie gipfelte in der Verdächtigung, die Jury habe Huber nur eine zweite Preis zuerkannt, da seinen Komposition einen Marx-Text enthalte, was bis dahin allerdings niemand bemerkt hatte, denn diese Quellenangabe fehlte in der der Jury vorliegenden Partitur' (Thomas, 'Von der Notwendigkeit', 9). The published version of the score gives a comprehensive list of the texts used, but even with the Marx citation thus identified, it is extremely difficult to identify exactly where in the score these interpolations occur, given the degree to which the text has been fragmented. 
prominent points of contention, although criticism of Darmstadt in the 1960s was hardly limited to these issues alone. First, the charge of academicism, levelled by Lewinski and Cardew in the remarks quoted at the start of this essay, was common: it had arisen particularly in the context of what were perceived as rather dry conferences on notation, form, and music theatre in 1964, 1965, and 1966 respectively. Second, Thomas's dismissal of Cage as a charlatan, and the effective bar on his participation that arose from this, was guaranteed to inflame tempers among the many West German Cage partisans. Third, in the wake of Steinecke's death, some perceived a struggle for supremacy to have broken out between Boulez and Stockhausen (most particularly, although Nono too was said to be involved to a lesser extent) for supremacy at Darmstadt. ${ }^{23}$ Despite this, many of the arguments that revolved around these points were, compared to what followed at the beginning of the 1970s, relatively quiet, or at least were carried on in private.

This underlying sense of unease, then, finally reached its zenith towards the end of the 1970 courses. The participants held two open meetings in the Justus-Liebig-Haus on 1 and 3 September to discuss the problems facing the Ferienkurse and to put forward proposals to Ernst Thomas for their solution. Thomas himself declined to attend the meetings. ${ }^{24}$ One of the more politically active regular Darmstadt participants, Hans G. Helms, opened the debate, acting as chairman throughout. Following him, Stockhausen spoke, giving a précis of the history of the courses. Later, in his public response to the meeting's criticism in the 1972 edition of the Darmstädter Beiträge zur Neuen Musik, Ernst Thomas was to quote from Stockhausen's résumé: 'Please, have no illusions that things might have been better earlier: that is simply a utopia! It may look like that, but it was always mediocrity and the average that represented the present, with a few "peak" performances coming out of it from time to time. ${ }^{25}$ However, Thomas may actually have been exacerbating the problem by using Stockhausen's words to defend himself. As Trapp points out, Stockhausen's speech at the first of the open meetings demonstrated, if any demonstration were necessary, that he remained the dominant figure at Darmstadt. This was to be precisely the first major criticism of many of the participants at that meeting: they wanted a broader fare of music to be represented. ${ }^{26}$

The second main criticism was directly related to the first. John Deathridge recalled that, although there was anxiety regarding Stockhausen's key role in the courses, it was also recognized that he was the only member of the lecturing staff who was really 'delivering' ${ }^{27}$ Ligeti, for instance, was charged with having given virtually the same lecture several times under different titles. ${ }^{28}$ If the standard of participants in the 1970 composition competition

23 Attinello, for instance, supports this view; 'The Interpretation of Chaos', 6.

24 'Niederrheinsicher Bauernbuddhismus', Abendzeitung, 9 September 1970.

25 'Bitte, machen Sie sich keine Illusionen, es sei früher besser gewesen, das ist alles Utopie! Das sieht so aus, aber es ist immer so gewesen, daß die Mediokrität und der Durchschnitt die Gegenwart repräsentiert haben, und einige Spitzenleistungen ab und zu daraus hervorgangen sind' (Thomas, 'Von der Notwendigkeit', 7).

26 'Hier wurde bereits deutlich, daß Stockhausen die beherrschende Figur jener Jahre war und genau hier die Kritik manche Teilnehmer ansetzte: man wollte ein breites Spektrum kompositorischer Richtungen erleben' (Trapp, 'Darmstadt und die 68-er Bewegung', 370).

27 Interview with the author, 3 December 2001.

28 See, for instance, Rudolf Frisius's polemical article 'Wer hat die Darmstädter Ferienkurse ruiniert?'. 
had been found wanting in the eyes of the lecturing faculty, so too the quality of the lecturing faculty fell somewhat short of the expectations of the participants.

It is not difficult to understand why there would be dissatisfaction both with Stockhausen's dominance, and with the lack of input from others. To grasp the reasons for Stockhausen's pre-eminence, it is necessary to look back over the history of his participation (and temporary non-participation) during the previous decade. Stockhausen had neither taught at nor attended Darmstadt in 1964 and 1965. For many years before this he had been discussing the idea of establishing a permanent music university in Cologne, based upon the Darmstadt model. Only when Hugo Wolfram Schmidt took over direction of the Rheinische Musikschule in 1962 did such plans begin to yield concrete results. Stockhausen's Cologne New Music Courses were given a three-month trial from 1 October 1963, with Pousseur teaching composition alongside Stockhausen and with Aloys Kontarsky, Frederic Rzewski, and Christoph Caskel on hand as instrumentalists. Thomas was evidently worried, perhaps understandably, by the competition that might ensue between Cologne and Darmstadt, particularly given that many of Stockhausen's teaching staff had already taught, or continued to teach, at Darmstadt. Thomas therefore felt compelled to ask Stockhausen to choose between Darmstadt and Cologne. Unsurprisingly, Stockhausen chose his own courses. ${ }^{29}$

While Thomas still had Boulez as a faculty member, Stockhausen's absence was palpable but not disastrous. When Boulez decided he would not return in 1966, however, it was evident that Ligeti's courses would not be sufficient to sustain the Ferienkurse, even with Kagel offering additional seminars focusing on music theatre. Thomas had little choice but to reinvite Stockhausen. It was this second period of his attendance that represented the acme of Stockhausen's influence on the artistic direction of Darmstadt.

The years 1967 and 1968 had been largely dominated by Stockhausen's two composition courses Ensemble and Musik für ein Haus, and 1969 by courses focusing on Aus den sieben Tagen. In 1970, although Ligeti had been allocated more course time than Stockhausen, it was again Stockhausen's six mammoth lectures that were the primary focus for many. ${ }^{30}$ Alongside this, Thomas's composition faculty had seemed distinctly lacklustre since Stockhausen's return: Ligeti and Günther Becker were the main contributors, with other figures, such as Lukas Foss, Kagel, and Lutosławski, participating only in subsidiary roles. Ligeti, Becker, and Kagel were, of course, familiar Darmstadt faces. Foss and Lutosławski were doubtless the more 'exotic' options, and so, in a situation in which the sameness of contributions was becoming problematic, their relegation to secondary status within the composition faculty was especially unfortunate. It was therefore unsurprising that the open meetings of 1970 chose to foreground these two related problems: that, while Stockhausen's

29 For a fuller description of these events see Kurtz, Stockhausen, 125-9.

30 The lectures were held between 27 August and 2 September under the titles 'Micro- and Macro-continuum', 'Metacollage and Integration', 'Expansion of the Tempo Scale', 'Feedback', 'Spectral Harmonics', 'Expansion of Dynamics', and 'Spatial Music' ('Spectral Harmonics' and 'Expansion of Dynamics' were separate parts of the same lecture). From 'Feedback' onwards these lectures began at eight in the evening and continued late into the night, well past midnight in many cases. A brief précis of the contents of these lectures is given in Stockhausen, Texte, vol. 3: Texte zur Musik 1963-70, 222-30. 
seminars were unquestionably the highlight of the courses, there really was little else to come to Darmstadt for.

The third issue raised in the open meetings likewise centred on concerns over the concentration of power; but this time the focus was on the director, who, it was argued, retained too much individual control over the courses. The participants felt that they themselves should have some say in the course content. The word Mitbestimmung-meaning 'co-determination', ordinarily in the sense of workers in a factory taking an active part in decisions regarding production - featured prominently in these discussions.

It would be tempting to regard the development of ideas of co-determination as related to left-wing political modes of thinking, bound up with the widespread student protests across Europe in the aftermath of the 1968 événements. Certainly this is true, but in the West German context a more specifically relevant and topical exemplar of this post-1968 mindset is to be found in the contemporary industrial campaigns of West German journalists. The right to co-determination had been established for most industries as early as 1952 in the 'works constitution law' (Betriebsverfassungsgesetz), but the law did not fully cover organizations active in areas that might be considered political, moral, or philosophical. Thus journalists working for the West German publishing houses did not have Mitbestimmung rights. By the late 1960s, though, one of the key aims of the Deutscher Journalisten-Verband (German Press Organization) had become the extension of such rights to its members. Specifically, and most pertinently in this context, the DJV sought clarity with regard to the division of competence between publishers and editors, which is to say the demarcation of areas of authority and responsibility. ${ }^{31}$ The importance of this relationship between journalists and the Darmstadt administration will become clearer below.

It was in this context, then, that concrete proposals were put forward for what the participants wished to see in future. Friedrich Hommel, Thomas's successor as music editor of the Frankfurter Allgemeine Zeitung, and later his successor as director of the Ferienkurse, summarized the key requests:

1 A greater emphasis on the composition seminars and the establishment of a composers' forum.

2 A strengthening of the genuinely international courses and concerts on offer, with increased involvement of the course participants.

3 A greater consideration of non-European music cultures.

4 Group teaching for practical improvisation and performance, in cooperation with the composers' forum.

5 Improvement of the facilities for electronic and computer music.

6 Greater consideration of 'fringe areas' (Grenzgebieten), such as film, music theatre, happenings, radio plays, pop music, and parapsychology.

7 The incorporation of aspects of research, through experts from the areas of sociology, critical theory, aural psychology and physiology, as well as information theory.

31 For further details see Humphreys, Media and Media Policy, 105-6. 
8 Better use of the available possibilities for democratization.

9 Suggestions for the redistribution of the budget, without which many of the proposals would be impossible. ${ }^{32}$

Hommel failed to point out two further issues raised by the meeting, both of which Klaus Trapp mentions. First, that either simultaneous translation of lectures should be offered in languages other than German, French, and English, or that translated texts of the lectures should be available. Second - an issue that may have seemed frivolous to Hommel but was of unquestionable importance to the participants - it was requested that the quality of the food be improved. ${ }^{33}$

In order that these proposals could be put forward to Ernst Thomas directly, the meeting elected five people as the so-called 'Darmstadt Delegation': the composers Tim Souster and Nicolaus A. Huber, the artist Mary Bauermeister-Stockhausen, the percussionist Christoph Caskel, and the journalist Reinhard Oehlschlägel. A further five were elected to act as deputies: the musicologist and journalist Rudolf Frisius, the composers Peter Michael Hamel and Junsang Bahk, the radio editor and composer Ernstalbrecht Stiebler, and the student Max E. Keller. ${ }^{34}$ One commentator raises the point that, since Stockhausen himself was one of the courses' strongest defenders, it is curious that his wife, Mary BauermeisterStockhausen, was elected as a member of the delegation. ${ }^{35}$ It is worth mentioning too that, despite the strongly expressed desire to hear more music from outside Europe, and most importantly from outside Germany, of the delegation only two were non-German: Souster, from Britain, and Bahk, from Korea. The structure of the delegation, specifically its division into panels of five, is particularly noteworthy. Given that one of the underlying principles of the delegation's demands was the notion of Mitbestimmung - the currency of which was, as mentioned above, mainly of journalistic origin in late 1960s West Germany - the model is surely most reminiscent of the structure of the Deutscher Presserat (German Press Council), which at its foundation in 1956 consisted of five representatives of newspaper publishers, five newspaper journalists, and, after 1957, five representatives from the magazine sector. ${ }^{36}$ The number of journalists acting as delegation members - three (Oehlschlägel, Stiebler, and Frisius) - also seems disproportionately high, given that nearly all of the ordinary course participants were either composers or performers.

A few days after the second meeting of the participants, Ernst Thomas published his initial reply to the criticism in the Darmstädter Tagblatt. ${ }^{37}$ He begins by questioning the validity of

32 Hommel, 'Neue Töne gesucht', Frankfurter Allgemeine Zeitung, 9 September 1970.

33 These additional points are mentioned by Trapp in 'Darmstadt und die 68-er Bewegung', 370. That the problem with food continues to the present day is attested by Pierre-Yves Artaud ('I have a piece . ..!') and by the present author, who experienced Darmstadt catering in 2002, 2004, and 2006.

34 See Trapp, 'Darmstadt und die 68-er Bewegung', 370.

35 'Niederrheinischer Bauernbuddhismus', Abendzeitung, 9 September 1970. Since Stockhausen and Bauermeister were basically estranged by this point (indeed in 1972 Bauermeister gave birth to a child by David Johnson, sometime member of the Stockhausen Ensemble), her presence on the delegation is unlikely to have been anything to do with Stockhausen's influence. It is perhaps more noteworthy that Bahk and Souster were pupils of Stockhausen.

37 'Experten bestimmen die Ferienkurse', Darmstädter Tagblatt, 8 September 1970. 
the delegation, observing that it was elected by less than half the total body of participants: this, he writes, 'raises the question of how far [their suggestions] can truly be considered representative of general opinion' ${ }^{38}$ He goes on to suggest that, far from being new, many of the suggestions being put forward had already been partially realized in earlier years, or had been discounted on financial grounds. While Thomas declares himself happy to receive suggestions of particular composers or performers as potential lecturers at Darmstadt, the maintenance of standards he considers to be his own ultimate responsibility. Preserving continuity from year to year is both necessary and desirable for the development of the courses. As mainstays ensuring this continuity Thomas specifically names Stockhausen and Ligeti as composers, and the violinist Saschko Gawriloff, the cellist Siegfried Palm, and Aloys Kontarsky as performers. He also observes that 'a broad spectrum of information can be beneficial, but it can also turn into a fatal pluralism, which causes confusion rather than being instructive'. ${ }^{39}$ Thomas thus directly states his intention to follow a specific trajectory, hoping for forward development through the continuity of lecturers, rather than by presenting the participants with the wide selection of trends requested by the delegation.

In his broadcast on the 1970 courses for Radio Zürich, Lewinski suggested that Thomas should now experiment with the structure of the courses, arguing that such an experiment would be better than having 'fatigue' become the primary reason for the courses' ultimate decay. ${ }^{40}$ With uncharacteristic optimism, Lewinski goes so far as to suggest the chance of a new beginning, but he is clearly not confident, even assuming that Thomas was willing to take the necessary risks, that it would be enough to secure the successful continuation of the Ferienkurse. $^{41}$

\section{A Well-Deserved Break? The Advisory Panel. New Structures}

'After 25 years in which the Darmstadt Ferienkurse have played a decisive part in the development of New Music, we believe a break is justifiable.' 42 So began 'Information I', a short press release published by the IMD in January 1971. This missive must have come as a great surprise to many of those intending to participate at Darmstadt in 1971, not least the members of the Darmstadt Delegation. The delegation, which had met as recently as October 1970 in Donaueschingen and had issued a press release of its own, must have felt somewhat

38 'Es erhebt sich natürlich die Frage, inwieweit es tatsächlich repräsentativ für die Meinungsbildung sein kann' ('Experten bestimmen die Ferienkurse', Darmstädter Tagblatt).

39 'Breite Information kann gut sein, aber sie kann auch in einem fatalen Pluralismus ausarten, der mehr Verwirrung stiftet als Unterrichtung bietet' ('Experten bestimmen die Ferienkurse', Darmstädter Tagblatt).

40 'Dennoch sollte Thomas versuchen, mit den Ferienkursen selbst zu experimentieren, neue Formen zu entwickeln[.] Es ist immer noch besser, wenn die darmstädter [sic] Ferienkurse an einem solchen Experiment zugrunde gehen als wenn sie durch Ermattung sterben' (IMD transcript of Kranichstein 1970, Radio Zürich, 6 November 1970).

41 'Die Chance zu einem Neubeginn ist vorhanden' (Kranichstein 1970, Radio Zürich).

42 'Nach 25 Jahren, in denen die Darmstädter Ferienkurse einen entscheidenden Beitrag zur Entwicklung der Neuen Musik geleistet haben, glauben wir, eine Pause verantworten zu können' (Thomas, 'Information I', IMD, January 1971). 
frustrated by the delay this would cause to their reforms. ${ }^{43}$ Nonetheless, 'Information 1' presented a number of the IMD's own reforms. Two further press releases followed: 'Information 2' in June 1971, and 'Information 3' in September 1971. Taken together, these documents seem to suggest a decisive rethink on the part of the courses' director.

However, these decisions, for once, had not been made by the director alone. Rather than taking the advice of the Darmstadt Delegation, Ernst Thomas had set up his own body, the so-called Programmbeirat, or advisory panel. The institution of this panel was approved by the city of Darmstadt's director of education and culture, Heinz-Winfried Sabais, who was also at that time acting mayor. ${ }^{44}$ The members of the advisory panel were Aloys Kontarsky, Siegfried Palm, and Christoph Caskel. Kontarsky and Palm were, of course, two of the three mainstay performers mentioned by Ernst Thomas in his response to the delegation, whereas Caskel was a member of the delegation itself.

The most significant piece of information given by the IMD's first press release in January 1971 is that the Ferienkurse would henceforth run biennially, starting in 1972 and continuing in the even-numbered years. However, the decision to switch to a biennial pattern had clearly not been made by Thomas's new advisory panel, since its first meeting did not take place until May $1971 .{ }^{45}$ Neither, in fact, had it been taken by Thomas, but on the civic authority of Sabais, for reasons that will be explained in more detail below. In compensation for the loss of every other year, the length of the courses was to be extended from two weeks to three. The first press release also promised a new 'working studio' (Arbeitsstudio), which would aim to provide a more collaborative environment for young composers. ${ }^{46}$ After the first meeting of the advisory panel, this studio was given a more concrete form, with the details provided in 'Information 2'. This press release contains a 'call for pieces', requesting that scores, tapes, and suggestions for collective work be sent to the IMD by 1 March 1972. It also promises that the studios will give the participants the opportunity to talk about their own pieces, analyse new compositions, discuss compositional problems, but 'above all to be active as composers' ${ }^{47}$ Although such studios had occasionally taken place at Darmstadt - most notably those led by Nono and Maderna in 1958, Stockhausen's seminars in 1961, and his two pre-courses Ensemble and Musik für ein Haus - the idea that young composers came to Darmstadt to present their work was one that had never really been formalized. Thus, in many ways, what Thomas and his advisory panel seemed to be proposing was quite radical for Darmstadt. The emphasis was being taken away from the established composers, who had tended to lecture

43 'Für Mitbestimmung bei Ferienkursen', Darmstädter Echo, 21 October 1970.

44 Caskel, 'Die Arbeit des Programmbeirats', 411. That Sabais took so great an interest in the changes to the Ferienkurse suggests that the city was also becoming anxious for the proper management of its investment. As the Ferienkurse were one of the city's great 'success stories', it is little surprise that the civic authorities would take an interest in ensuring their successful continuance.

45 Caskel, 'Die Arbeit des Programmbeirats', 411.

46 'Die wird auch ermöglichen, ein bereits für 1970 projektiertes Arbeitsstudio junger Komponisten nun in größerem Umfang stattfinden zu lassen: zur Mitarbeit in diesem Studio rufen wir bereits jetzt die jungen Komponisten auf' (Thomas, 'Information 1').

47 'Den Teilnehmer soll die Möglichkeit geboten werden, über eigene Kompositionen zu referieren, neue Kompositionen zu analysieren, Probleme heutigen Komponierens zu erörtern, vor allem aber kompositorisch tätig zu sein’ (Thomas, 'Information 2'). 
on their own work, and transferred to the new work being brought by the participants. This change of focus was confirmed by Thomas's stated intention that the results of the studio work should, as far as possible, be realized and discussed within the boundaries of the courses, and that the young performers should be working on the scores of the young composers. ${ }^{48}$ The third press release, from September 1971, makes this proposal still clearer, suggesting that where possible one of the lecturers would be working with the participants. Most important, however, is the statement that this work would then be publicly presented in studio concerts, for which 'programme suggestions [...] are requested from the participants'. ${ }^{49}$ Again, until this point, the idea that a young composer might bring a piece to Darmstadt and have it played at the end of the courses would have been a fanciful one. Despite the flexibility of the Internationales Kammerensemble Darmstadt (IKD), under the direction of Maderna, the programming of concerts was largely set in stone by the time the courses actually took place. In seeming disregard of Thomas's earlier warnings concerning the dangers of a 'fatal pluralism', 'Information 3' expresses the hope that with these new provisions 'a broad spectrum of New Music can be considered'. ${ }^{50}$ Christoph Caskel reports that the members of the advisory panel themselves were somewhat sceptical of this new development: the real impetus for change came from Ernst Thomas himself. Caskel states that Thomas wanted more dialogue between the participants and the lecturers, and was clearly keen to break down the perceived divisions. ${ }^{51}$ Thomas was also surely aware that, with this shift in emphasis, he was taking a large risk: it was necessary that the standards of both young performers and composers remain high for Darmstadt to continue. Yet, in answer to his critics, he was also demonstrating clearly that responsibility for programming was now shared between the IMD executive and the participants.

The second press release also explains the detailed new technical provisions for the electronic studio, which appears by now to have been furnished with some of the most up-to-date equipment. Even so, participants were asked to bring certain items with them, such as synthesizers, ring modulators, and contact microphones. Presumably, despite the rebuilt studio, the IMD remained unable to provide sufficient equipment for all the participants. The considerable improvement in the technical facilities met one key demand of the Darmstadt delegation, and the provision of a number of new projectors met another, by enabling investigations into the 'fringe area' of film.

The new stress on composition within the boundaries of the courses is emphasized by one of the most surprising changes announced by 'Information 3'. Despite the fiasco of the 1970 composition competition, the Kranichsteiner Musikpreis was to be revived, with two awards made at the conclusion of the Ferienkurse, one for the best performance by a student and one

48 'Arbeitsergebnisse sollen soweit wie möglich noch innerhalb der Kurse realisiert und diskutiert werden, wobei eine Zusammenarbeit mit jungen Interpreten unter den Teilnehmern angestrebt wird' (Thomas, 'Information 2').

49 'Vorschläge für das Studioprogramm von Seiten der Teilnehmer sind erwünscht' (Thomas, 'Information 3').

50 'damit ein breites Spektrum Neuer Musik berücksichtigt werden kann' (Thomas, 'Information 3').

51 'Wie so etwas aussehen könnte, blieb zu Anfang vage und unumschrieben - klar wie nur, daß derartige Kompositionsstudios sich in Richtung auf eine "dialogischere" Vermittlung (so Wolfgang Rihm in einem späteren Kommentar) entwickeln sollten’ (Caskel, 'Die Arbeit des Programmbeirats’, 412). 
for the best new composition presented within the studio concerts. The sum available for the first of this new round of Kranichstein awards was 4000 marks. ${ }^{52}$

Not mentioned in the IMD press releases, however, is one of the most significant changes. Many of the regular participants at Darmstadt had for several years bemoaned the fact that the courses no longer took place in a single location, which had been the Marienhöhe, a private school, until 1965. Between 1966 and 1970 the primary location for lectures had been the Justus-Liebig-Haus in the centre of the city. However, many other events had had to be scattered across Darmstadt, diminishing the sense of a unified programme and depriving the participants of opportunities to communicate and intermingle. Social interaction was further inhibited by the fact that the participants were housed in various different sites across the city. While the housing situation could not be solved immediately, the advisory panel felt that a new central location for the courses was vital. The ideal choice would be another school building, with halls suitable for lectures and concerts, classrooms suitable for the studio work, and a canteen creating a central meeting point for the participants to eat together. At the suggestion of Wilhelm Schlüter, who was responsible for the administrative aspects of the courses and the IMD archive, the Georg-Büchner-Schule was selected. Its proximity to the IMD building was a further factor in its favour. ${ }^{53}$ Indeed, before suggesting it to the panel members, Schlüter had made arrangements with the headmaster of the school in anticipation of their agreement. ${ }^{54}$

The basis of some of the advisory panel's changes, and in particular the innovations concerning the composition classes, appears to have been some remarks made by Boulez in a radio broadcast for the Hessischer Rundfunk. There Boulez expressed the view that 'Darmstadt must remain, with fewer people, and perhaps lasting longer'. In an article in the Darmstädter Beiträge Ernst Thomas not only quotes that phrase, ${ }^{55}$ but also mentions further remarks by Boulez, made in an interview in Christ und Welt, to the effect that composers at Darmstadt should be encouraged to compose less and to think about composition more. What had been lost, for Boulez, was any rigorous preparation for composition,

52 Given in the 1972 course plan held at the IMD. There were to be seven recipients of the prize in 1972: for composition, Gillian Bibby, Hellmut Cromm, and Martin Gelhorn; for performance, Herbert Henck, Suzanne Stephens-Myers, Gabriele Schumacher, and Yukiko Sugawara.

53 The Georg-Büchner-Schule is on the same street as the IMD building, Nieder-Ramstädter-Straße. They are also directly linked on the Darmstadt tram network, with the Georg-Büchner-Schule at the Jahnstraße tram stop and the IMD building only two stops away, directly opposite the terminus of the present line 9, Böllenfalltor. It is hard to imagine a more convenient site for the courses, especially given the benefit of the location, midway between the two, of the sports hall, where numerous other lectures and performances would take place. The courses remained at the Georg-Büchner-Schule until 2002.

54 'Die Lösung des Problems kam dann, wie so oft, von Wilhelm Schlüter: Er hatte nicht nur die Büchner-Schule als in vieler Hinsicht ideales Gebäude in die engere Wahl einbezogen, sondern auch in kürzester Frist eine Besichtigung vereinbart; darüber hinaus hatte er auch dem Einverständnis des Schulleiters schon vorgearbeitet!' (Caskel, 'Die Arbeit des Programmbeirats', 411-12).

55 'Darmstadt muß bleiben, vielleicht auf eine größere Lange, nur mit weniger Leute' (Boulez, contribution to the broadcast Die etablierte Musik-Avantgarde, Hessischer Rundfunk Second Programme, 9 November 1969; transcript: IMD); quoted by Ernst Thomas in 'Von der Notwendigkeit'. Boulez was perhaps thinking of a model more akin to Stockhausen's Cologne Courses or, indeed, what would become IRCAM. 
the lack of which appeared to go hand in hand with the increased attention being paid to improvisation. ${ }^{56}$

However, there can be no doubt that, whatever the political expediency of the new structures, one of the primary imperatives forcing change at Darmstadt was a fiscal one. Sabais, newly elected mayor in addition to his responsibility for culture and education, had found serious deficits in the city's budget. In 1971 these were reported as being in the region of 13.3 million marks, ${ }^{57}$ and by early 1972 they had risen to 16.1 million. ${ }^{58}$ Indeed, in the first newspaper reports of the Ferienkurse's switch to a biennial pattern, financial considerations are accorded the most importance; the annual cost of the Ferienkurse to the city is quoted as being in the region of 165,000 marks. Despite the changes, the IMD was to be awarded 45,000 marks in each 'off' year in order to allow for improvements in the IMD's technical provisions. ${ }^{59}$ Klaus Trapp makes the point subtly but effectively when he refers to the change to a two-year pattern as a 'decision of the city of Darmstadt', ${ }^{60}$ the implication being that Thomas found himself publicly defending a decision that had been presented to him by Sabais as a fait accompli. Lewinski seems to suggest, though, that a number of options may have been open to the courses' director: 'It looks', he writes, 'as if Ernst Thomas had toyed around with the idea of this break, so that finances would not become the single determining factor.' ${ }^{61} \mathrm{He}$ is less charitable when he continues: 'There is nothing to be said against a break, as long as it brings constructive consequences, and does not signal an exodus.' 62

\section{The Hausverbot}

The real reason for the failure of the student protest, and at the same time the reason behind the advisory panel's comparative success, is, in fact, implicit in Ernst Thomas's response to the so-called 'Darmstadt Delegation', and specifically in his stated desire to achieve continuity from year to year. ${ }^{63}$ In short, the rapidly changing make-up of the participants, with more than sixty-five per cent attending each year for the first time, ${ }^{64}$ meant that any genuine continuity was practically impossible. As a concession to the 1970 protest, a discussion evening was held during the 1972 courses. The evening made it quite clear that, although

56 This complaint regarding improvisation may be seen as a not-so-veiled criticism both of Stockhausen's Ensemble and Musik für ein Haus courses, and perhaps most especially of Aus den sieben Tagen.

57 'Ohne “Trick siebzehn” eine bittere Haushalts-Wahrheit', Darmstädter Tagblatt, 23 January 1971.

58 'Defizit liegt jetzt bei 16 Millionen Mark', Darmstädter Echo, 14 April 1972.

59 See, for instance, 'Ferienkurse eingeschränkt', Spandauer Volksblatt, 6 February 1971; 'Ferienkurse für neue Musik nur noch alle zwei Jahre', Süddeutsche Zeitung, 6 February 1971.

60 'Nachdem der 1971 von der Stadt Darmstadt gefaßte Entschluß, die Ferienkurse fortan im Zweijahrrhythmus zu veranstalten' (Trapp, 'Darmstadt und die 68er-Bewegung, 369).

61 'Es sieht so aus, als ob Ernst Thomas mit dieser Pause sowieso geliebäugelt hatte, sie sich nicht erst von den Finanzen dikterien ließ' (Lewinski, 'Ende der Ferienkurse?').

62 'Nichts gegen eine Pause, wenn sie konstruktive Konsequenzen zeitigt, keinen Exodus signalisiert' (Lewinski, 'Ende der Ferienkurse?').

63 Success is meant here simply in the sense that the Advisory Committee continued in its role until Thomas's retirement in 1981.

64 In 1972, according to the statistics provided by the Darmstädter Beiträge, roughly eighty per cent of participants were attending for the first time. 
many did wish for debate, many simply wanted to get on with the activities that had brought them to Darmstadt in the first place. During the discussion a participant from Eastern Europe reportedly shouted out, 'I want to make music!' ${ }^{65}$ When the election of the following year's delegation took place, only thirty participants voted. ${ }^{66}$ The changes in participation from year to year, in terms of both numbers and countries represented, created a situation in which, whatever the levels of dissatisfaction, the discontents could never bank on sufficient support. Moreover, as was implied by the predominant nationality of the elected members of the Darmstadt Delegation, the objections directed against the structures and ethos of the courses chiefly reflected West German preoccupations and, more particularly, those of West German journalists. Even though, in the period from 1972 to 1980, between twenty-five and thirty per cent of the participants were West German, so many of them must have been attending Darmstadt for the first time that only a minority would have been likely to be genuinely sympathetic to the cause of unseating Thomas in favour of an elected committee, or even entirely au fait with the precise terms of the debate. Indeed, a substantial proportion of the German contingent may have been broadly favourable towards certain of Thomas's positions. ${ }^{67}$ In this sense, with the exception of flashpoints such as that of 1970 , no organized protest against the institution could have any guarantee of success. Conversely, the more or less guaranteed presence of the advisory panel from year to year gave the institution a continuity of ideology and purpose that the protesters were never likely to achieve. It is also perhaps worth mentioning a further, somewhat basic but significant disparity between the parties: the participants would have had to pay their own way in order to come to Darmstadt and protest, while the advisory panel would have been paid for their contribution. 1972, however, would show what small-scale protest could achieve - a single but nonetheless mortal blow to the perceived authority of the director and the advisory panel, even if it was the bungled handling of this protest by the IMD executive that ultimately did the most to achieve this result.

The protest of 1972 originated with three journalists whose attendance would certainly have been subsidized, if not fully paid for, by their respective newspaper and broadcasting companies: Reinhard Oehlschlägel, Ernstalbrecht Stiebler, and Rudolf Frisius. ${ }^{68}$ All were members or deputies of the previous Darmstadt Delegation, as were the two others involved, Nicolaus A. Huber and Max E. Keller. The reduction in numbers of the protesting faction from a voting body of half the Ferienkurse participants to a small coterie of five is clearly crucial, whether it ought to be taken as suggesting widespread, albeit perhaps grudging, support for the changes instituted by Thomas and the advisory panel or, equally likely, apathy and disillusionment after the events of 1970. Significantly, all five of the current group had been directly complicit in the 1970 protest. Indeed, if the events of that year can be

65 Trumpff, 'Diskussion über die Ferienkurse'.

66 'Delegations-Dilemma', Darmstädter Tagblatt, 5 August 1972.

67 This may, for instance, have been the case with Thomas's refusal to invite Cage. Although the more vocal discussions of Cage's presence in Germany are largely favourable, often uncritically so, there was an equally large proportion of feeling that Cage was indeed the 'charlatan' Thomas had branded him.

68 As mentioned above, Stiebler was a composer as well as a radio editor at the Hessischer Rundfunk. Frisius, meanwhile, was active as a musicologist in addition to his journalistic writing. 
considered analogous to the activism of a trade union, Reinhard Oehlschlägel could aptly be viewed as its shop steward. ${ }^{69}$

Rudolf Frisius, for his part, had already publicized his opinion in an article for the Neue Musikzeitung entitled 'Who Has Ruined the Darmstadt Ferienkurse?'. ${ }^{70}$ The 'crisis', in Frisius's opinion, was a 'crisis of the system', and the responsibility for the Darmstadt system, it was clear, lay squarely with the director of the Institute. ${ }^{71}$ Perhaps unfairly, Frisius fails to note the city's generally parlous financial situation when he comments that the decision of the Darmstadt authorities to decline to fund the courses in 1971 was quite understandable, since their quality had sunk so low. ${ }^{72} \mathrm{He}$ also mentions as a further cause of difficulties at Darmstadt the rising wave of factionalism, though without considering the part his own article might have to play in this divisiveness. Stiebler, too, had made a similar, though rather less polemical, statement in an interview for the Hessischer Rundfunk, commenting on the general 'stagnation' of new music and suggesting that the break in the courses in 1971 had been dictated by artistic as much as financial problems. ${ }^{73}$

By the time the 1972 courses began, however, it seemed that much of this public squabble had petered out. There had been little further criticism in the press or on the radio, and the courses themselves reached their third week without particular incident. However, on 1 August the Darmstädter Echo was the first to report that three journalists - only Oehlschlägel is referred to by name - had been issued with a Hausverbot, banning them from attending any of the public lectures or concerts, and also forbidding them to enter the Georg-BüchnerSchule. ${ }^{74}$ The paper reported that the ban had been issued the previous day, 31 July 1971,

69 Again - and perhaps still more strongly - the group of five is reminiscent of the structure of the Deutscher Presserat and its own five-member panels.

70 'Wer hat die Darmstädter Ferienkurse ruiniert?' (1971).

71 'Die Darmstädter Krise ist eine Krise des Systems' (Frisius, 'Wer hat die Darmstädter Ferienkurse ruiniert?').

72 'Das Niveau ist inzwischen so gesunken, daß [. . . [ es] völlig verständlich [ist], wenn ausgerechnet in diesem Stadium die Stadt Darmstadt, die die Ferienkurse 1971 nicht mehr finanzieren will, zur Subventionierung einer Darmstädter Enzyklopädie der Neuen Musik überredet will' (Frisius, 'Wer hat die Darmstädter Ferienkurse ruiniert?').

73 This interview was broadcast on Das Musikjournal, Hessischer Rundfunk, 29 January 1971 (transcript available at the IMD). Ernst Thomas himself broadcast a response on the same radio station on 3 February 1971, suggesting that he did not feel it particularly helpful to talk of a general crisis in new music itself (transcript also available at the IMD).

74 'Hausverbot für Journalisten', Darmstädter Echo, 1 August 1972. Trudu (La 'Scuola' di Darmstadt, 220) fails to assess the correct sequence of events, presuming that Thomas barred the protesters from the courses and that, in response, Oehlschlägel quite reasonably aired his grievances. Furthermore, Trudu seems to presume that it was Oehlschlägel's pamphlet that created the need for a discussion evening, so that Thomas could explain himself. On the contrary, however, Oehlschlägel was distributing a pamphlet seen by Thomas as inflammatory in advance of a general meeting, which Thomas had already planned as a concession to the demands of the Darmstadt Delegation. Thus, in response, Thomas barred the protesters. Thomas's actions are, in any case, much more understandable as a reaction than as a pre-emptive strike of some sort. Trudu's error is no doubt in part a result of having used a later national press source, the more ostensibly reputable Frankfurter Allgemeine Zeitung, rather than one of the two local newspapers. Unlike the Darmstädter Echo, the Frankurter Allgemeine Zeitung gives no indication of the date of the ban. This mistake is certainly understandable because of the post-war condition of press concentration in West Germany, where many of the local papers, such as the Darmstädter Echo, became nothing more than subsidiaries of larger press groups. The local papers were still marketed as if they were independent organs, but their contents would be conspicuously similar to other local papers, often with little more than a change of cover sheet. Trudu was perhaps presuming that the first printing of a story would take place on the same day across an entire West German media group. For more information on press concentration in West Germany see Humphreys, Media and Media Policy, 74-83. According to Beal, however, the letters to the pamphlet signatories were dated 30 July 1972. Since the discussion evening also took 
with Ernst Thomas commenting that it was in response to 'the calumnious activities that have been clearly in evidence since 1970' ${ }^{75}$ Oehlschlägel is quoted in the same article as claiming that the ban was issued specifically in order to prevent his distribution of a pamphlet detailing the Darmstadt Delegation's opinion of the continuing flaws in the decision-making procedures, as well as the actual programme of the courses, in advance of the discussion meeting mentioned above. ${ }^{76}$ Although no copy of this pamphlet appears to have survived, the consensus seems to be that the Melos article entitled 'The 1970 Darmstadt Delegation Considers the Results', credited in that publication to all five members of the Delegation, is identical to it. ${ }^{77}$

Despite the ban, it seems clear that the issues outlined by Oehlschlägel's pamphlet still reached the discussion evening. At the start of the evening Thomas explained to the participants the reasons for the issuing of the ban. It seems that the same letter had been sent to each of the journalists, as well as to Max Keller. Thomas read an extract of it to the assembled participants: 'You have signed a pamphlet containing direct untruths and spiteful manipulations of the facts directed against the course director and the advisory panel, by which you have supported attempts to stir up the participants and poison the working atmosphere. ${ }^{78}$ If the pamphlet was indeed identical to the Melos article, Thomas's letter comes across as extreme in its reaction. The Melos article, in fact, compliments the leadership for having broadened the outlook of the courses to include Kagel, Xenakis, and Wolff in the 1972 programme. Beyond that, its six key demands, paralleling those Gustav Adolf Trumpff reports as having featured in the original pamphlet, ${ }^{79}$ were as follows:

1 For professional translators, both to increase the number and enhance the experience of participants from non-German-, non-French-, and non-English-speaking countries.

place on 30 July 1972, and none of the signatories was present, these letters must have been hand-delivered to them; see Beal, 'Patronage and Reception History', 257.

75 'weil sie - wie der Institutsdirektor am Montag auf Anfrage erklärte - Auflagen für ihre Zulassung nicht erfüllten und “die bereits seit 1970 gezeigten verleumderischen Aktivitäten” nicht unterließen' ('Hausverbot für Journalisten', Darmstädter Echo).

76 'Demgegenüber erklärte einer der betroffenen Journalisten, der Deutschlandfunk-Redakteur Reinhard Oehlschlägel (Köln), mit dem Hausverbot solle lediglich verhindert werden, daß den Kursteilnehmern mit einem Flugblatt der Bericht einer Delegation zur Kenntnis gebracht werde, in dem sowohl die Entscheidungsstruktur als auch die mangelnde Aktulität des Programms kritisiert wird' ('Hausverbot für Journalisten', Darmstädter Echo).

77 Oehlschlägel and others, 'Die Darmstädter Delegation von 1970 zieht das Fazit'. In an interview with Amy Beal, Rudolf Frisius stated that the pamphlet and the article were identical with each other. Antonio Trudu also treats them as if they were so.

78 Given that the content of Thomas's speech here and the content of the letter acquired by Amy Beal from Ursula Stiebler are identical, it seems likely that an identical letter was indeed sent to each of the signatories. The complete German text as given by Beal reads as follows: ' $\mathrm{Zu}$ unserem Bedauern haben wir festgestellt, daß Sie ein gegen die Kursleitung und den Programmbeirat gerichtetes Unwahrheiten in der Sache und böswillige Verdrehungen enthaltendes Pamphlet unterzeichnet und damit den Versuch unterstützt haben, die Teilnehmer aufzuwiegeln und die Arbeitsatmosphäre zu vergiften. Wir sehen uns daher genötigt, Ihnen ab sofort den Besuch sämtlicher Veranstaltungen der Ferienkurse, auch der öffentlichen, sowie das Betreten der Georg-Büchner-Schule zu untersagen' (see Beal, 'Patronage and Reception History', 257). Klaus Trapp quotes Thomas's speech; see 'Darmstadt und die 68-er Bewegung', 372. Beal appears to suggest that Thomas held the meeting specifically to explain his decision. However, this meeting is more likely to have been one of the already planned discussion forums, and Oehlschlägel's pamphlet was almost certainly being distributed in readiness for this event.

Trumpff, 'Diskussion über die Ferienkurse'. 
2 For a discussion on the new beginning offered by a political music aesthetic.

3 For a comparative reduction in the number of performances by established composers, such as Kagel, Xenakis, Ligeti, and Stockhausen.

4 For an increase in the number of performers. ${ }^{80}$

5 For the institution of press conferences, and greater press involvement in Ferienkurse activities.

6 For the resignation of the current advisory panel and the election of a new one, in the light of Thomas's refusal to allow the Darmstadt Delegation to participate in the decisionmaking process. ${ }^{81}$

At the discussion evening, which, owing to the ban on their presence in the Georg-BüchnerSchule, none of the protesters could attend, Aloys Kontarsky, flanked by Caskel and Palm, responded to some of Oehlschlägel's criticisms. Kontarsky argued that lectures by Dahlhaus and Brinkmann on the subject of 'Political and Aesthetic Criteria for the Critique of Composition', as well as the performance of Nicolaus A. Huber's Harakiri (1971-2), represented clear steps in the direction of a discussion on musico-political aesthetics. He also retorted that the newly introduced composers' and performers' studios, along with the studio concerts at the end of the courses, would allow a much broader spectrum of music to be presented by the actual participants, as well as from the 'big name' composers. ${ }^{82}$ With regard to the question of professional translation, Ligeti and Dahlhaus both warned that, in their experience, the use of non-musically competent professional translators could result in more confusion than illumination, ${ }^{83}$ and that, moreover, most of the lecturers had already given their lectures in several languages, or at least provided a written summary in other languages. ${ }^{84}$

The last two points of criticism raised by the pamphlet seem to have given Thomas and the advisory panel the impression that much of its agenda was bound up with Oehlschlägel's own journalistic concerns. At least, this was quickly adopted as the IMD's 'official line' against the criticism. The Hausverbot against Stiebler was quickly retracted because he was due to take part in a performance of Schnebel's Atemzüge on 1 August 1971, and that of Max Keller was withdrawn because he was an active participant in the courses, not a journalist, although the

80 It is unclear for what purpose more performers were required. Given the state of the studio concerts in the early 1980s, when student string players would complain of near-physical attack to secure their services, it seems most likely that Oehlschlägel is pointing out that, although in theory the studio concerts allow young composers to have their music performed, there are insufficient student instrumentalists to make a greater number of performances of student work viable.

81 The protesters' third point is particularly anomalous: having only just acknowledged the benefits of including Kagel and Xenakis in the Darmstadt faculty, they appear now to criticize them for being too established.

82 See Trapp, 'Darmstadt und die 68-er Bewegung', 373.

83 'Zum anderen warnten György Ligeti und Carl Dahlhaus aus eigenen schlechten Erfahrungen, daß musikalisch nicht kompetente Dolmetscher mehr Verwirrung als Nutzen stiften' (Trumpff, 'Diskussion über die Ferienkurse').

84 'Fast alle Dozenten haben auch in diesem Jahr ihre Kurse und Vorträge mehrsprachig gehalten oder wenigstens ein schriftliches fremdsprachiges Resümee gegeben' (Trumpff, 'Diskussion über die Ferienkurse'). Ligeti, for example, had given his lectures three times, in German, English, and French. Xenakis had taken a show of hands at the beginning of his first lecture to ascertain the most suitable language for his presentation, which, as a result, was given in English. 
intervention of various members of the lecturing staff assisted this conclusion. ${ }^{85}$ The antijournalistic stance was echoed in Aloys Kontarsky's response to Oehlschlägel, published alongside the pamphlet text in Melos. There Kontarsky insisted that the programme was drawn up for the participants, not the press. ${ }^{86}$ However, it soon became clear that the use of this stance to defend the imposition of the Hausverbot had been a damaging misjudgement. ${ }^{87}$ Trapp relates that fellow reporters of Oehlschlägel, Frisius, and Stiebler quickly began to complain that the ban represented a restriction of press freedom, ${ }^{88}$ and Thomas was forced, somewhat embarrassingly, to have to defend himself in public once more. ${ }^{89}$ Even so, it seems likely that the discontent implied by Oehlschlägel's pamphlet was far from as widespread as might be inferred. The numbers involved in the new elections for a fresh Darmstadt Delegation would hardly have been sufficient to form a quorum in any ballot. Furthermore, Frisius himself has claimed not only that he did not sign the pamphlet, but also that he saw a copy of it only after the Hausverbot had been issued, Oehlschlägel having written it independently. ${ }^{90}$ As for the mass of the participants, their attitude, arguably just as dangerous for the institution itself, may well have been, in truth, one of apathy.

In an article for the Frankfurter Allgemeine Zeitung Friedrich Hommel presents a view of events that seems strongly to endorse the opinion that this particular 'scandal' was a product of media spin rather than of general disquiet. Ostensibly, this article represents Hommel's annual review of the Ferienkurse. Yet it is much lengthier than the pieces he had previously delivered for this purpose, and the main thrust deals with an examination of the media pressure against Ernst Thomas since 1969. Hommel seeks to demonstrate that the bulk of the political and media activity against the leadership of the Ferienkurse can be traced back ultimately to Oehlschlägel, although he also mentions articles by Frisius and Stiebler, as well as a television programme made by Hans G. Helms at the 1970 courses for the Westdeutscher Rundfunk. He defends Thomas's view that Darmstadt should be governed on the basis of artistic rather than political decisions, even if the artistic decisions would be those of the director and the advisory panel. He also underlines the irony of the fact that the protests profess the ambition of democratization. Since the dissent had come from only a small faction of the press, their proposals for change could hardly be considered more democratic than the decisions taken by the director of the IMD. Hommel reminds his readers that even

85 'Den Ausschluß von Herrn Keller haben wir auf Fürsprache von Dozenten zurückgenommen - weil er Teilnehmer ist' ('Drohen weitere Aussperungen?', Darmstädter Tagblatt, 7 August 1972).

86 'Wir haben die Programme für die Teilnehmer, nicht für die Presse, aufgestellt' (Kontarsky, 'Antwort', 361).

87 Frisius was a university lecturer by profession. In a later exchange of correspondence between himself and Thomas he suggests that, because he was not a professional journalist, he had not acted 'improperly' by describing the Ferienkurse as he had. Where a journalist would be expected to provide an entirely balanced approach, as a lecturer it was entirely reasonable that he had provided a much more personal reaction. This exchange was prompted by Frisius's application to come to the 1974 Ferienkurse. Thomas pronounced himself 'entirely astonished' that Frisius wished to return, in a letter dated 6 June 1974 (held at the IMD).

88 Trapp, 'Darmstadt und die 68-er Bewegung', 372. See, for instance, Ignée, 'Die Moral von Darmstadt', and Jungheinrich, 'Kampfsprache der Unfreiheit'.

89 See the interview 'Drohen weitere Aussperrungen?', Darmstädter Tagblatt, 7 August 1972.

90 See Beal, 'Patronage and Reception History', 256-7, nn. 72-3. It is worth noting nonetheless that Frisius's signature was not withdrawn from the version published in Melos a few months later; see Oehlschlägel and others, 'Die Darmstädter Delegation von 1970 zieht das Fazit’. 
at Darmstadt's most politically dynamic moment, namely the 1970 courses, the Darmstadt Delegation had been elected by less than half the body of participants. He concludes by agreeing with Oehlschlägel that the 'Darmstadt Affair', as he terms it, was a scandal, but a scandal that merely exposed the dubious practices of a small journalistic clique. ${ }^{91}$ Hommel's article, though no doubt intended in part as a defence of Ernst Thomas, had the effect of sparking a fresh round of argument, with further vitriol on both sides. ${ }^{92}$ The damage this continuing quarrel caused to the already blemished public image of the Ferienkurse was considerable.

As Trudu observes, with this Hausverbot 'for Thomas, the door was closed on renewal once and for all'. ${ }^{93}$ Although it is quite clear that Thomas, Caskel, Kontarsky, and Palm had begun to institute many changes, some of which were certainly in line with the requests of the Darmstadt Delegation, it is equally clear that this further public squabble at Darmstadt injured Thomas's leadership irrevocably. For here the media, which were responsible for the common perception of Darmstadt, directly challenged Thomas. Not only that, but Thomas's position was damaged further by the failure of his actions: the Hausverbot itself was clearly disproportionate; it hardly represented the democratic touch that was required. Moreover, Stiebler and Keller were readmitted after only a day, and Oehlschlägel and Frisius attended the public events of the Ferienkurse in defiance of the ban. Ernst Thomas somewhat limply claimed that the fact that further steps were not taken against Frisius and Oehlschlägel, despite their continuing presence, was representative of the 'liberality' of the Darmstadt leadership. ${ }^{94}$

Whatever its motives, the protest of 1972 exposed the impotence of the Darmstadt leadership to challenge criticism. Despite an apparently burgeoning institutional restructuring, the inept handling of both this and the previous protest of 1970 created a situation in which renewal was blocked for the foreseeable future. This is to say that, even were regeneration to achieve success on an organizational level, it would no longer be reported as such by the media, whose pessimism would continue unabated until the retirement of Ernst Thomas. Genuine artistic renewal at Darmstadt would now have to wait until the tenure of Hommel in the 1980s. While Thomas's reforms had undoubtedly prepared the ground for his successor, the damage done to his leadership by the crisis of 1972 ensured that he would never be allowed to take due credit for them. The events of the years either side of Darmstadt's twenty-fifth anniversary seriously undermined the efficacy of the institutional

91 Hommel, 'Musik nach revolutionärem Gesamtkonzept?'.

92 The October-November 1972 issue of the Neue Musikzeitung carries a lengthy article from Rudolf Frisius ('Ein musikalisches Forum verliert sein Format') that is critical but hardly unfair. However, in the December 1972January 1973 issue Oehlschlägel and Hommel are once again in direct conflict, and even Sabais is drawn into the argument. The debate had also reached the Swiss press, with an article in the Basel-based National-Zeitung by Max Keller ('Seltsame "Demokratien” in Darmstadt') criticizing Gustav Trumpff's reporting of events. Trumpff's reply, heavily laced with sarcasm, appears not to have been printed, but a copy of the text, dated 18 August 1972, is available in the IMD archive.

93 'Fu praticamente con quello Hausverbot che la porta del rinnovamento si chiuse definitivamente alle spalle di Thomas' (Trudu, La 'Scuola' di Darmstadt, 222).

94 'Daß wir nicht gegen ihr [Frisius and Oehlschlägel] Erscheinen eingeschritten sind, darf man als Zeichen unser Liberalität verstehen' ('Drohen weitere Aussperrungen', Darmstädter Tagblatt, 7 August 1972). 
framework that had supported the post-war avant-garde and, amidst what now seemed like the crumbling edifice of the avant-garde's chief fortress, all that appeared to remain standing, seemingly forgotten in the institutional conflict of the previous three years, was the courses' central figure, Karlheinz Stockhausen. ${ }^{95}$

\section{Radio Broadcasts}

Die etablierte Musik-Avantgarde. Hessischer Rundfunk Second Programme, 9 November 1969. Transcript: Internationales Musikinstitut Darmstadt (IMD).

Kranichstein 1970. Radio Zürich, 6 November 1970. Transcript: IMD.

Das Musikjournal. Hessischer Rundfunk Second Programme, 29 January 1971.

\section{Bibliography}

\section{Unsigned newspaper articles (alphabetical by title)}

[F. B.], 'Defizit liegt jetzt bei 16 Millionen Mark'. Darmstädter Echo, 14 April 1972.

'Delegations-Dilemma'. Darmstädter Tagblatt, 5 August 1972.

'Drohen weitere Aussperungen?'. Darmstädter Tagblatt, 7 August 1972.

'Experten bestimmen die Ferienkurse'. Darmstädter Tagblatt, 8 September 1970.

'Ferienkurse eingeschränkt'. Spandauer Volksblatt, 6 February 1971.

'Ferienkurse für neue Musik nur noch alle zwei Jahre'. Süddeutsche Zeitung, 6 February 1971.

'Für Mitbestimmung bei Ferienkursen'. Darmstädter Echo, 21 October 1970.

'Gefährdetes Forum der Avantgarde'. Weser-Kurier [Bremen], 8 September 1970.

'Hausverbot für Journalisten'. Darmstädter Echo, 1 August 1972.

'In Darmstadt blast ein frischer Wind'. Basler Nachrichten, 16 September 1970.

'Kritik an den Etablierten'. Hessische Allgemeine, 10 September 1970.

'Niederrheinsicher Bauernbuddhismus'. Abendzeitung [Munich], 9 September 1970.

[K. S.], 'Ohne “Trick siebzehn” eine bittere Haushalts-Wahrheit'. Darmstädter Tagblatt, 23 January 1971, p. 10.

\section{General}

Artaud, Pierre-Yves. 'I have a piece ...!', in Von Kranichstein zur Gegenwart, ed. Stephan and others. 543-8.

Attinello, Paul. 'The Interpretation of Chaos: a Critical Analysis of Meaning in European Avant-Garde Vocal Music, 1958-68'. PhD diss., University of California, Los Angeles, 1997.

Bach, Hans-Elmar, 'Laute Mißtöne bei den Darmstädter Kursen’. Kölnische Rundschau, 7 September 1970.

Beal, Amy C. 'Patronage and Reception History of American Experimental Music in West Germany, 1945-1986'. $\mathrm{PhD}$ diss., University of Michigan, 1999.

Becker, Wolfgang. 'Da Darmstadt: i corsi estivi della nuova musica'. Nuova rivista musicale italiana 4/6 (1970), 1162-4.

Borio, Gianmario. Musikalische Avantgarde um 1960: Entwurf einer Theorie der informellen Musik. Laaber: Laaber-Verlag, 1993.

Cardew, Cornelius. 'New Music Has Found its Feet'. Financial Times, 31 July 1964.

Caskel, Christoph. 'Die Arbeit des Programmbeirats', in Von Kranichstein zur Gegenwart, ed. Stephan and others. 411-14.

Dahlhaus, Carl. 'Musik zwischen Politik und Ästhetik'. Darmstädter Tagblatt, 31 July 1972.

—_. 'Politische und ästhetische Kriterien der Kompositionskritik'. Darmstädter Beiträge zur Neuen Musik 13 (1973), 14-27.

Frisius, Rudolf. 'Wer hat die Darmstädter Ferienkurse ruiniert?'. Neue Musikzeitung 20 (April-May 1971), 1-2.

_. 'Ein musikalisches Forum verliert sein Format'. Neue Musikzeitung 21 (October-November 1972).

95 Stockhausen would not remain at Darmstadt for much longer. The sort of small-scale protest that was capable of damaging Thomas's leadership in 1972 had similar ramifications for Stockhausen in 1974, although Stockhausen himself was responsible in part for his own downfall. In response to his expulsion of a Finnish student from his courses in 1974, a small group of leftist composers, Johannes Vetter, Gerhard Stäbler, and Jürgen Lösche, issued a pamphlet that seemed to reflect the general feeling at the 1974 courses that Stockhausen was out of touch and had overstayed his welcome. This combined with the unfavourable reception of Herbstmusik (1974) left the advisory panel with little option but to demand his removal from the courses, probably against Thomas's own wishes. 
Griffiths, Paul. The Thames and Hudson Encyclopaedia of 20th-Century Music. London: Thames and Hudson, 1986. Hommel, Friedrich. 'Neue Töne gesucht'. Frankfurter Allgemeine Zeitung, 9 September 1970.

. 'Musik nach revolutionärem Gesamtkonzept?'. Frankfurter Allgemeine Zeitung, 18 August 1972.

. 'Gott zum Gruß'. Neue Musikzeitung 21 (December 1972-January 1973), 8; incl. responses by Reinhard Oehlschlägel and Heinz-Winfried Sabais.

Humphreys, Peter J. Media and Media Policy in Germany. Oxford: Berg, 1990.

Ignée, Wolfgang. 'Die Moral von Darmstadt'. Stuttgarter Zeitung, 3 August 1972, p. 25.

Jungheinrich, Hans-Klaus. 'Kampfsprache der Unfreiheit'. Frankfurter Rundschau, 23 August 1972, p. 8.

Keller, Max E. 'Seltsame “Demokratien” in Darmstadt'. National-Zeitung [Basel], 16 August 1972.

Kontarsky, Aloys. 'Antwort'. Melos 39 (1972), 361.

Kurtz, Michael. Stockhausen: a Biography, trans. Richard Toop. London: Faber and Faber, 1992.

Lewinski, Wolf-Eberhard von. 'Alte und neue Experimente bei Kranichsteinern'. Melos 33 (1966), 321-3.

'Auch ein nacktes Mädchen kann die Moderne nicht retten'. Allgemeine Zeitung [Mainz], 31 August 1970. . 'Ende der Ferienkurse?'. Darmstädter Tagblatt, 25 January 1971.

Oehlschlägel, Reinhard. 'Dokumentation und Preis'. Stuttgarter Zeitung, 1 September 1970.

— von 1970 zieht das Fazit'. Melos 39 (1972), 360-1.

Schiffer, Brigitte, 'Darmstadt, Citadel of the Avantgarde'. The World of Music 9/3 (1969), 33-44.

Stephan, Rudolf, and others, eds. Von Kranichstein zur Gegenwart: 50 Jahre Darmstädter Ferienkurse. Stuttgart: DACO, 1996.

Stockhausen, Karlheinz. Texte, vol. 3: Texte zur Musik 1963-70, ed. Dieter Schnebel. Cologne: DuMont, 1963.

Thomas, Ernst. 'Information I'. Internationales Musikinstitut Darmstadt (IMD), January 1971.

-. 'Information 2'. IMD, June 1971.

'Information 3'. IMD, September 1971.

—. 'Von der Notwendigkeit, Ferienkurse für Neue Musik zu veranstalten'. Darmstädter Beiträge zur Neuen Musik 13 (1973), 6-13.

Trapp, Klaus. 'Darmstadt und die 68-er Bewegung', in Von Kranichstein zur Gegenwart, ed. Stephan and others. 369-75.

- 'Die siebziger Jahre', in Von Kranichstein zur Gegenwart, ed. Stephan and others. 403-8.

Trudu, Antonio. La 'Scuola' di Darmstadt: i Ferienkurse dal 1946 a oggi. Milan: Ricordi/Unicopli, 1992.

Trumpff, Gustav. 'Diskussion über die Ferienkurse'. Darmstädter Echo, 2 August 1972. 